\title{
Mathematics and Theology in the Thought of Nicholas of Cusa
}

\author{
Roman Murawski
}

\begin{abstract}
Nicholas of Cusa was first of all a theologian but he was interested also in mathematic and natural sciences. In fact philosophicotheological and mathematical ideas were intertwined by him, theological and philosophical ideas influenced his mathematical considerations, in particular when he considered philosophical problems connected with mathematics and vice versa, mathematical ideas and examples were used by him to explain some ideas from theology. In this paper we attempt to indicate this mutual influence. We shall concentrate on the following problems: (1) the role and place of mathematics and mathematical knowledge in knowledge in general and in particular in theological knowledge, (2) ontology of mathematical objects and their origin, in particular their relations to God and their meaning for the description of the world and physical reality, (3) infinity in mathematics versus infinity in theology and their mutual relations and connections. It will be shown that-according to Nicholas - mathematics and mathematical thinking are tools of rationalization of theology and liberating it in a certain sense from the trap of apophatic theology.
\end{abstract}

Mathematics Subject Classification. Primary 00A30; Secondary 03A05.

Keywords. Nicholas of Cusa, Mathematics, Theology, Infinity.

\section{Nicholas' Life and Scientific Career}

Before investigating Nicholas' thought let us say some words about his life and career. It will indicate also the scientific and mental environment in which he lived and worked.

Nicholas of Cusa was born in 1401 as as Nicholas Kryffs or Krebs in Kues, now Bernkastel-Kues, about $30 \mathrm{~km}$ from Trier, an old town in the Palatinate, founded already by the Romans. His name often appears as Nikolaus Cusanus, from the Latin name of the town. He was sent to Deventer, in the Netherlands where he probably attended a school of Brothers of Common Life, 
a Roman Catholic religious community founded in the fourteenth century. In 1416 Nicholas matriculated at the University of Heidelberg where he studied liberal arts, particularly philosophy. Next year he went to the University of Padua to study there canon law-he graduated with doctorate in canon law in 1423. In 1425 he matriculated at the University of Cologne to study philosophy and theology. There he was introduced to the ideas of Pseudo-Dionysius, Albertus Magnus and Raymond Lull. After finishing his studies he began his legal activity. In 1431-1437 he took part in the Council of Basel. In 1433 he wrote De concordantia catholica arguing that the Council's authority took precedence over that of the pope. In 1436 Nicholas changed sides and became an adherent of pope's camp. In 1438 pope Eugenius IV sent him as a member of a three-man delegation to Constantinople. The aim of the delegation was to set up a process leading to the eastern and western Churches reuniting. The stay in Constantinople was important for Nicholas also from the point of view of his scientific activity - he discovered there some important Greek manuscripts.

Between 1438 and 1448 Nicholas took part in several missions to Germany as papal envoy. Sometime between 1436 and 1440 he ordained and was named cardinal by pope Eugenius IV in 1446 in recognition of his work as papal envoy. However Eugenius IV died and Nicholas had to wait till 1448 when pope Nicholas $\mathrm{V}$ made him a cardinal. He became the bishop of Brixen (now Bressanone) in 1450. Unfortunately he could not take up his duties there for two years and pope sent him as papal legate to North Germany and the Netherlands. His aim was to prepare the Christians to the Jubilee of 1450 .

In Brixen Nicholas began to reform the local Church what caused him trouble. In 1460 he was imprisoned by the local ruler Sigismund. Set free he left his diocese and settled in Rome. He died in Todi in 1464. According to his wishes his body was buried in Rome and his heart in his home town Kues.

\section{The Role of Mathematics and Mathematical Knowledge}

Having presented main facts from Nicholas' life let us turn now to his work and thought. Nicholas' interests in mathematics and natural sciences began in his Padua days. He met there Paolo dal Pozzo Toscanelli and they stayed friends throughout Nicholas' life. Toscanelli became later an important mathematician and astronomer. Thanks to contacts with him he learned in Padua about the latest developments in mathematics and astronomy. In his scientific investigations in mathematics Nicholas was interested in geometry and logic. He had clearly made a study of at least parts of Euclid's Elements and works of Thomas Bradwardine and Campanus of Novara. He contributed to the study of infinity, studying the infinitely large and the infinitely small. He looked at the circle as the limit of regular polygons and used it in his religious teaching to show how one can approach truth but never reach it completely. In many his papers he considered the problem of squaring the circle and of measuring the circumference of a circle. It should be noticed however that his 
mathematical writings did not attain top level in rigour - in fact he was rather a good amateur.

Nicholas was also interested in astronomy and his achievements were highly appreciated. For example Giordano Bruno is said to have written: "If [Nicholas of Cusa] had not been hindered by his priest's vestment, he would have even been greater than Pythagoras!".

Nicholas in his philosophical investigations was particularly interested in the theory of knowledge. He claimed that knowledge is derived through the senses but understanding is an abstraction of diverse sensory images. All human knowledge must be mere conjecture, and wisdom is attained only through understanding the extent of one's ignorance. He was convinced that the human knowledge is only an approximation of the truth (coniectura).

Nicholas attributed a special role to mathematical knowledge - in fact it possesses the highest degree of precision and clarity. According to him, mathematics is the best way of preparing the human mind to theological considerations. In De docta ignorantia (On Learned Ignorance) [9, Book I, Chapter 11] he wrote:

[...] thus, Boethius, the most learned of the Romans, affirmed that anyone who altogether lacked skill in mathematics could not attain a knowledge of divine matters. ${ }^{1}$

And he added (ibidem):

[...] since the pathway for approaching divine matters is opened to us only through symbols, we can make quite suitable use of mathematical signs because of their incorruptible certainty. ${ }^{2}$

Mathematics was important for Nicholas not only with respect to theology and theological considerations but he treated it as a model of all veritable knowledge. The reason is the fact that in mathematics one uses numbers and figures constructed by the mind without any reference to the physical reality which is changeable and to the knowledge about it. Even more: objects of mathematics are within the powers of the mind only and they emulate the activity of God. In De docta ignorantia [9, Book II, Chapter 13] he wrote:

And so, God, who created all things in number, weight, and measure, ${ }^{3}$ arranged the elements in an admirable order. (Number pertains to arithmetic, weight to music, measure to geometry. $)^{4}$

He refers to the idea of creation of the world by God writing (ibidem):

\footnotetext{
${ }^{1}[\ldots]$ ita ut Boethius, ille Romanorum litteratissimus, assereret neminem divinorum scientiam, qui penitus in mathematicis exercitio careret, attingere posse.

$2[\ldots]$ ad divina non nisi per symbola accedendi nobis via pateat, quod tunc mathematicalibus signis propter ipsorum incorruptibilem certitudinem convenientius uti poterimus.

${ }^{3}$ Wisd. $11,21$.

${ }^{4}$ Admirabili itaque ordine elementa constituta sunt per Deum, qui omnia in numero, pondere et mensura creavit. Numerus pertinet ad arithmeticam, pondus ad musicam, mensura ad geometriam.
} 
In creating the world, God used arithmetic, geometry, music, and likewise astronomy. (We ourselves also use these arts when we investigate the comparative relationships of objects, of elements, and of motions.) For through arithmetic God united things. Through geometry He shaped them, in order that they would thereby attain firmness, stability, and mobility in accordance with their conditions. $^{5}$

According to Nicholas numbers and other mathematical objects play an indispensable role in any knowledge and in any rational and intellectual process. Any knowledge is expressed by numbers, there is no knowledge without numbers because thinking means to count, to measure and to compare. One can see here certain similarity to the doctrine Pythagoreans.

\section{Ontology of Mathematical Objects}

What is the position of mathematical objects in the structure of being? Nicholas claimed that they posses an intermediate position and located them between physical, material and changing objects and the reality treated by theology which is fixed and free of any change. ${ }^{6}$ Mathematical objects though not free of change, still they are fixed and certain as being the constructions of the mind and in constructing them the mind is internally bounded only by the principle of consistency.

Nicholas distinguished numbers that are objects of mathematics and numbers coming from God. The latter have their origin on God's mind and find their reality in the variety of sensually intelligible objects, the former are constructions of human mind in accordance with the God's numbers, they are images (ymago) of numbers existing in God. In Idiota de mente [10, Chapter 9] he wrote:

Mind makes number; hence, multitude and magnitude derive from mind. And, hence, mind measures all things. ${ }^{7}$

In Chapter 6 one finds the following words:

I deem the Pythagoreans - who, as you state, philosophize about all things by means of number - to be serious and keen [philosophers]. [...] Rather, they were speaking symbolically and plausibly about the number that proceeds from the Divine Mind - of which number a mathematical number is an image. For just as our mind is to the Infinite, Eternal Mind, so number [that proceeds] from our mind

\footnotetext{
${ }^{5}$ Est autem Deus arithmetica, geometria atque musica simul et astronomia usus in mundi creatione, quibus artibus etiam et nos utimur, dum proportiones rerum et elementorum atque motuum investigamus. Per arithmeticam enim ipsa coadunavit; per geometriam figuravit, ut ex hoc consequerentur firmitatem et stabilitatem atque mobilitatem secundum condiciones suas $[\ldots]$.

${ }^{6}$ On Nicholas' conceptions concerning mathematics see [12].

${ }^{7}$ Mens [...] facit numerum, unde multitudo et magnitudo a mente sunt, et hinc omnia mensurat.
} 
is to number [that proceeds from the Divine Mind]. And we give our name "number" to number from the Divine Mind, even as to the Divine Mind itself we give the name for our mind. And we take very great pleasure in occupying ourselves with numbers, as being an instance of our occupying ourselves with our own work. ${ }^{8}$

The fact that numbers of mathematics are images of God's numbers implies that numbers and other mathematical objects are good symbols of the essences of things. In particular various kinds of the reality can be symbolised by various kinds of numbers and unities. In particular the divine unity - and the Unity is one of the main descriptions of God - can be symbolized by the number one which is the first arithmetical unit and the principle of all numbers. In fact one speaks here about numbers called by mathematicians natural numbers on the base of which all other types of numbers (integers, rational umbers, real numbers, complex numbers) can be constructed.

Objects of geometry were treated by Nicholas in a similar way as numbers. They are images of objects existing in God's mind and are created by the mind. In Idiota de mente [10, Chapter 9] he wrote:

Mind makes a point to be the termination of a line, makes a line to be the termination of a surface, and makes a surface to be the termination of a material object. ${ }^{9}$

The way in which they are created is explained by Nicholas in Chapter 9 of Idiota de mente [10] in the following way:

Philosopher: How does the mind make a line?

Layman: By considering length without width. And [mind makes] a surface by going on to consider width without solidity. (However, neither a point nor a line nor a surface can actually exist in this way, for outside the mind only solidity actually exists.) Thus, the measure or end-point of each thing is due to mind. Stones and pieces of wood have a certain measurement - and have endpoints - outside our mind; but these [measurements and end-points] are due to the Uncreated Mind, from which all the end-points of things derive. ${ }^{10}$

\footnotetext{
${ }^{8}$ Arbitror autem viros Pythagoricos, qui ut ais per numerum de omnibus philosophantur, graves et acutos. [...] sed symbolice ac rationabiliter locuti sunt de numero, qui ex divina mente procedit, cuius mathematicus est imago. Sicut enim mens nostra se habet ad infinitam aeternam mentem, ita numerus nostrae mentis ad numerum illum. Et damus illi numero nomen nostrum sicut menti illi nomen mentis nostrae, et delectabiliter multum versamur in numero quasi in nostro proprio opere.

${ }^{9}$ Mens facit punctum terminum esse lineae et lineam terminum superficiei et superficiem corporis.

${ }^{10}$ PHILOSOPHUS: Quomodo facit lineam? IDIOTA: Considerando longitudinem sine latitudine, et superficiem considerando latitudinem sine soliditate, licet sic actu nec punctus nec linea nec superficies esse possit, cum sola soliditas extra mentem actu exsistat. Sic omnis rei mensura vel terminus ex mente est. Et ligna et lapides certam mensuram et terminos habent praeter mentem nostram, sed ex mente increata, a qua rerum omnis terminus descendit.
} 
Mathematical objects are made by human mind thanks to the ability of assimilation ${ }^{11}$ called also abstraction. ${ }^{12}$ One can see here a form of empiricism - compare Chapter 2 of Idiota de mente [10] where Nicholas writes:

So whoever thinks that in the intellect there can be nothing that is not present in reason also thinks that in the intellect there can be nothing that was not first in the senses. ${ }^{13}$

\section{Infinity in Mathematics Versus Infinity in Theology}

An important place in Nicholas' considerations both mathematical as well as philosophical and theological has the problem of the infinity. ${ }^{14}$ He claims that the infinity can be somehow grasped - however not accurately - in mathematics by mind with the help of concepts, but it cannot be grasped with the help of senses. It should be stressed that the reason and the aim for considering the infinity in mathematics was for Nicholas an attempt to approach the infinity of God. He introduced a new and innovative thought about this infinity. He qualified the infinity of God as the coincidentia oppositorum.

Nicholas argued that infinity cannot be characterized in terms of quantity, it cannot be quantified. In fact there is no way from quantity to infinity. Cusanus objected to Aristotle's idea of potential infinity because it is based on an infinite progression of finite quantities. Infinity cannot be measured. On the other hand it is the measure of everything else and it is unique. Infinity defies also any logical treatment. The infinite has no proportion to the finite, hence it will never be known from the finite.

Mathematics can help us to understand the infinity, in particular God's infinity. It can be done by symbolic illustration, in particular by mathematical symbols. Analogies and mathematical metaphors are the best way to understand the nature of God. Mathematics is the best way that can prepare the mind for theology - as mentioned already above. One should try to understand mathematical properties of finite mathematical objects and then analyze the way in which these properties change when these objects are increased to infinity. For example Nicholas argues that the infinite line, the circle and the triangle coincide in infinity. This should show that opposites coincide and fall together in infinity. This is the method of mathematical analogy. In De docta ignorantia he wrote [9, Book I, Chapter 12]:

For since all mathematicals are finite and otherwise could not even be imagined: if we want to use finite things as a way for ascending to

\footnotetext{
${ }^{11}$ Compare the title of Chapter 7 of Idiota de mente: CHAPTER SEVEN: Mind produces from itself, by means of assimilation, the forms of things; and it attains unto absolute possibility, or matter. [Quomodo mens a se exserit rerum formas via assimilationis et possibilitatem absolutam seu materiam attingit.]

${ }^{12}$ Cf. De docta ignorantia, [9, Book II, Chapters 1 and 4].

${ }^{13}$ Quicumque igitur putat nihil in intellectu cadere posse, quod non cadat in ratione, ille etiam putat nihil posse esse in intellectu, quod prius non fuit in sensu.

${ }^{14}$ For the problem of infinity in Cusanus' writings cf. $[1-8,13]$.
} 
the unqualifiedly Maximum, we must first consider finite mathematical figures together with their characteristics and relations. Next, [we must] apply these relations, in a transformed way, to corresponding infinite mathematical figures. Thirdly, [we must] thereafter in a still more highly transformed way, apply the relations of these infinite figures to the simple Infinite, which is altogether independent even of all figure. At this point our ignorance will be taught incomprehensibly how we are to think more correctly and truly about the Most High as we grope by means of a symbolism. ${ }^{15}$

The importance of mathematics in Nicholas of Cusa'a thought and its role in acquiring the knowledge about God, in particular the meaning of geometrical and theological figures can be illustrated by the proportion:

Christ : particular human nature $=$ theological figures : geometrical figures.

The infinity cannot be realized in any process. In fact among things and processes that can be acquainted by senses there is nothing that could not be increased and expanded. However in mathematics there are examples showing that a limit of a process can be grasped by a concept. Nicholas gives here an example of a sequence of regular polygons of $\mathrm{n}$ sides. If $\mathrm{n}$ grows unboundedly then the polygons approximate better and better a circle. Among object cognizable by senses there exists no circle. A circle exists only as a concept in our mind. In Idiota de mente [10, Chapter 7] he wrote:

[...] as, for example, when it conceives a circle to be a figure from whose center all lines that are extender to the circumference are equal. In his way of existing no circle can exist extra-mentally, in matter. ${ }^{16}$

Hence circle and regular polygon of $n$ sides - though different objects - coincide in the infinity. In a similar way the limit of a sequence of circles that are tangent to a given line at one fixed point and whose radius grows to the infinity can be grasped as a concept - namely by a concept of a line (cf. Chapter 13 of De docta ignorantia, [9]). In general different geometrical figures (circles, spheres, lines, triangles) can be identified with one another when they are increased to the infinite. In particular the infinite circle and the infinite line can be identified.

We have to do here with a principle called by Nicholas coincidencia oppositorum. It can be applied not only in mathematics but also in nonmathematical domains. One has to do with it when an unlimited object is

\footnotetext{
${ }^{15} \mathrm{Nam}$ cum omnia mathematicalia sint finita et aliter etiam imaginari nequeant: si finitis uti pro exemplo voluerimus ad maximum simpliciter ascendendi, primo necesse est figuras mathematicas finitas considerare cum suis passionibus et rationibus, et ipsas rationes correspondenter ad infinitas tales figuras transferre, post haec tertio adhuc altius ipsas rationes infinitarum figurarum transumere ad infinitum simplex absolutissimum etiam ab omni figura. Et tunc nostra ignorantia incomprehensibiliter docebitur, quomodo de altissimo rectius et verius sit nobis in aenigmate laborantibus sentiendum.

${ }^{16}[\ldots]$ dum concipit circulum esse figuram, a cuius centro omnes lineae ad circumferentiam ductae sunt aequales, quo modo essendi circulus extra mentem in materia esse nequit.
} 
never given but can be grasped only by finite approximations. The completion of a process (and simultaneously its limit) have for Cusanus the highest form of being and are eternal because the process itself seeks its own completion.

What are the relations between the infinite and the finite. Nicholas claims that the finite cannot guarantee the existence of the infinite because the latter will be never reached in a process of approximation by finite elements, the infinite does not borrow its existence from finite objects. The infinite is first in the order of being. The finite can be understood and grasped only with the help of the infinite. In Idiota de mente Nicholas wrote [10, Chapter 2]:

Consequently, everything finite is originated from the Infinite Beginning. 17

The principle of coincidentia oppositorum was used by Cusanus also in mathematics as a tool for creating the new mathematical procedure of infinite approximation - for example to calculate the circumference of a circle. He even wrote in De mathematica perfectione [11, Sect. 2]: "My aim is to improve mathematics by concidentia oppositorum". ${ }^{18}$

One can look at the principle of coincidentia oppositorum as at the reflection of Nicholas' understanding of epistemology as an approximate process towards the truth.

Note that Nicholas of Cusa liberated in a certain sense rationality in theology from the trap of apophatic theology. The latter claims that the infinity of God cannot be accessed rationally. In Nicholas of Cusa's approach the ontological infinity of God is transformed into infinity of epistemological processes in mathematics, but also in physics and philosophy. However a human being is not able to acquire the full knowledge about God since God is infinite and gap between the finite human mind and God's infinity is immense.

Open Access. This article is distributed under the terms of the Creative Commons Attribution 4.0 International License (http://creativecommons.org/licenses/ by/4.0/), which permits unrestricted use, distribution, and reproduction in any medium, provided you give appropriate credit to the original author(s) and the source, provide a link to the Creative Commons license, and indicate if changes were made.

Publisher's Note Springer Nature remains neutral with regard to jurisdictional claims in published maps and institutional affiliations.

\section{References}

[1] Achtner, W.: Infinity in science and religion: the creative role of thinking about infinity. Neue Zeitschrift für systematische Theologie und Geschichtsphilosophie 47, 392-411 (2005)

\footnotetext{
${ }^{17}$ Quare omne finitum principiatum ab infinito principio.

${ }^{18}$ Intentio est ex oppositorum coincidentia mathematicam venari perfectionem.
} 
[2] Achtner, W.: Infinity as a transformative concept in science and technology. In: Heller, M., Hugh Woodin, W. (eds.) Infinity. New Research Frontiers, pp. 19-51. Cambridge University Press, Cambridge (2011)

[3] Albertson, D.: Mathematical Theologies: Nicholas of Cusa and the Legacy of Thierry of Chartres. Oxford University Press, New York (2014)

[4] Breidert, W.: Mathematik und symbolische Erkenntnis bei Nikolaus von Kues. Mitteilungen und Forschungsbeiträge der Cusanus-Gesellschaft 12, 116-126 (1977)

[5] Counet, J.-M.: Mathematics and the Divine in Nicholas of Cusa. In: Koetsier, T., Bergmans, L. (eds.) Mathematics and the Divine: A Historical Study, pp. 273-290. Elsevier, Amsterdam (2005)

[6] Federici Vescovini, G.: Cusano e la matematica. In: Filosofia e storia della cultura. Studi in onore di Fulvio Tessitore, vol. 1: Dall'antico al moderno, Napoli, pp. 392-434 (1997)

[7] Federici Vescovini, G.: L'architettonica della mente di Cusano e la matematica. In: Le origini della modernità, a cura di W. Tega, vol. I: Linguaggi e saperi tra XV e XVI secolo, Firenze, pp. 31-48 (1998)

[8] Knobloch, E.: Unendlichkeit und Mathematik bei Nicolaus aus Kues Grundideen und ihre Weiterentwicklung. In: A. Schürmann und B. Weiss (Hrsg.), Chemie - Kultur - Geschichte. Festschrift für Hans-Werner Schütt anlässlich seines 65. Geburtstages. Verlag für Geschichte der Naturwissenschaften und der Technik, Berlin/Diepholz, pp. 223-234 (2002)

[9] Nicolai de Cusa: De docta ignorantia (1440). In: Opera omnia, vol. I, ediderunt: Hoffmann, E., Klibansky, Lipsiae, R. 1932. Novam editionem curavit Burkhard Mojsisch 2008. English translation: On Learned Ignorance, The Arthur J. Banning Press, Minneapolis, Minnesota 1985 (second edition), (second printing) (1990)

[10] Nicolai de Cusa: Idiota de mente (1450). In: Opera omnia, vol. V, edidit Steiger, R., Hamburgi 1983. Novam editionem curavit Burkhard Mojsisch 2008. English translation: Layman on Mind, in: Nicholas of Cusa On Wisdom and Knowledge, The Arthur J. Banning Press, Minneapolis, Minnesota (1996)

[11] Nicolai de Cusa: De mathematica perfectione (1458). In: Editio Argentoratensis 1488, vol. II, pp. 490-498. Nova edition. P. Wilpert, Berlin (1967)

[12] Nicolai de Cusa: Les écrit mathématiques, présentation, traduction et notes par J.-M. Nicolle, Honoré Champion, Paris (2007)

[13] Pasqua, H. (ed.): Infini et altérité dans l'oeuvre de Nicolas de Cues (1401-1464), Éditions de l'Institut Supérieur de Philosophie, Louvain-la-Neuve (2017)

Roman Murawski

Faculty of Mathematics and Computer Science

Adam Mickiewicz University

Uniwersytetu Poznańskiego 4

61-614 Poznan

Poland

e-mail: rmur@amu.edu.pl

Received: September 19, 2017.

Accepted: August 30, 2019. 